\title{
Correction to: Saving the Manx Shearwater Flea Ceratophyllus (Emmareus) fionnus (Insecta: Siphonaptera): The Road to Developing a Recovery Plan for a Threatened Ectoparasite
}

\author{
Mackenzie L. Kwak ${ }^{1}$ - Allen C. G. Heath ${ }^{2} \cdot$ Ricardo L. Palma $^{3}$
}

Published online: 21 November 2019

(c) Witold Stefański Institute of Parasitology, Polish Academy of Sciences 2019

\section{Correction to: Acta Parasitologica \\ https://doi.org/10.2478/s11686-019-00119-8}

Due to a processing error, the presentation of Table 1 was incorrect. The corrected Table 1 is given below. The original article has been corrected.

The original article can be found online at https://doi.org/10.2478/ s11686-019-00119-8.

Mackenzie L. Kwak

mackenziekwak@gmail.com

1 Evolutionary Biology Laboratory, Department of Biological Science, National University of Singapore, 16 Science Drive 4, Singapore 117558, Singapore

2 Animal Science Group, AgResearch Ltd, Hopkirk Research Institute, Massey University, Private Bag 11008, Palmerston North 4442, New Zealand

3 Museum of New Zealand Te Papa Tongarewa, 169 Tory Street, Wellington 6011, New Zealand 
Table 1 Fleas recorded in association with the Manx shearwater (Puffinus puffinus) in the British Isles

\begin{tabular}{|c|c|c|}
\hline Species/subspecies & Localities & References \\
\hline Ceratophyllus borealis Rothschild, 1906 & Skokholm Island & Stansfield [30] \\
\hline Ceratophyllus fionnus [34] & Isle of Rùm & Usher [34] and Wormell [38] \\
\hline $\begin{array}{l}\text { Ceratophyllus vagabundus insularis Roths- } \\
\text { child, } 1906\end{array}$ & Skokholm Island & Stansfield [30] \\
\hline Ornithopsylla laetitiae Rothschild, 1908 & $\begin{array}{l}\text { Isles of Scilly; Skokholm } \\
\text { Island; Isle of Rùm }\end{array}$ & $\begin{array}{l}\text { Turk [33], Stansfield [30], } \\
\text { Russel [26] and Wormell } \\
\text { [38] }\end{array}$ \\
\hline Spilopsyllus cuniculi Dale, 1878 & Skokholm Island & Lockley [18] \\
\hline
\end{tabular}

